\title{
Student Financial Aid and Its Role in Stimulating Enrollment: An Empirical Study of Tanzanian Undergraduate Students' Experience
}

\author{
Robert Lucas Kaniki $^{1 *} \quad$ Dr. Juliet Hoh Chui Suan ${ }^{2}$ \\ 1.Institute of Education and Research, Xiamen University, 422 Siming South Road, Xiamen 361006, China \\ 2.Higher Education Division, Ministry of Education, P.O. Box 1541, Bandar Seri Begawan, BS 8673, Brunei \\ Darussalam
}

This research received no specific financial support

\section{Abstract}

This paper provides an important insight into the undergraduate students' reliance on financial aid and its role on student enrollment. Based on the finding emerging from the focus groups and semi-structured interview; five general themes emerged, including economic condition and higher cost, unmet needs, limited contribution from universities, lack of information about financial aid opportunities and inadequate of private financial aid. Findings have implications and future research for administrators in higher education, government and policymakers.

Keywords: Student financial aid; enrollment; Tanzanian undergraduate students; higher education, Tanzania

DOI: $10.7176 / \mathrm{JEP} / 11-26-11$

Publication date:September $30^{\text {th }} 2020$

\section{Introduction}

Universities can be viewed as institutions that produce social elites. In most recent times the rising cost of universities has begun to limit their accessibility to underprivileged students (Cabrera, Nora, \& Castaneda, 1993; Gillen, 2010). Regardless of the financial aid opportunities available, low-income students in Tanzania are not being admitted in universities at the same rate as their wealthier peers; due to inadequate financial aid which affects initial enrolment at a university (Ishengoma, 2011). Studies reveal that the enrollment ratio in sub-Saharan Africa is still low compare to other regions of the world and significantly lower than South Asia, which is second to last (Gandhi, 2018; World Bank, 2017). Owing to this, students from the lowest socio-economic background will always have less chances of entering a university than those from wealthy socio-economic backgrounds if no effort is made to adopt policies aimed at enabling the enrollment of more students from low-income backgrounds (UNESCO, 2009)

The enrollment ratio in Tanzania universities is still low compared to neighboring and other Southern Africa Development Community (SADC) countries like South Africa and Zambia. The limited financial aid programs targeting low-income students seeking admission into universities was revealed as one of the factors of the low enrollment rates in Tanzanian universities (Ishengoma, 2011). This study explored undergraduate students' experiences on the role of financial aid in stimulating enrollment in university, with the believe that its revealed results will raise awareness among university administrators, government authorities, student affairs practitioners, and other education stakeholders on the need to intensify their efforts in supporting students by considering the primary goals of financial aid which are: promoting universities' enrollment, affordability and equality of opportunity to needy students. As, these actions are important to consider when initiating financial aid policies in higher education institutions (Conrods, 2008; Gillen, 2010)

\subsection{Research Questions}

To explore students' perspectives on the role of financial aid in helping them to enroll in higher education, this study takes qualitative questions to examine the topic and issues discussed. It explores students' perspectives by examining the following research questions:

RQ1. How do students at Tanzanian universities describe the role of financial aid in stimulating enrollment in university?

RQ2. What obstacles do students encounter in the current financial aid program?

\section{Theoretical Approach}

As mentioned in the literature review, financial aid plays a great role in increasing students' enrollment and retention, making higher education cheaper for students and their families, and ensuring that disadvantaged students can study in universities (Gillen, 2010). Yet, despite the increasing importance of financial aid around the World, there are little research in Tanzanian higher education focus specifically on students' experience of the role of financial aid in stimulating enrollment in university and obstacles that students encounter in the financial aid programs. Thus, students' experience is one framework through which this study was centered. 
This study is further framed by resource theory particularly from a specific perspective of resource availability (Dorsch, Törnblom \& Kazemi, 2016; Hobfoll, 1989, 2002). Hobfoll (2002) define resource as asset that a person values for their characteristics or as a means to accomplish a desired end-state. While an asset refers to any object such as product, offerings or money (Dorsch, Törnblom \& Kazemi, 2016). Therefore, the resources availability in resource theory, refers to the extent to which the resource is obtainable (accessible) for use when needed (Dorsch, Törnblom \& Kazemi, 2016). Resources availability posits that availability of resources such as fiscal resources (financial aid, endowments, and extramural research funds) in education enhance student learning and development.

Resource theory specifically emphasize the importance of providing adequate resources to students. The policymakers, government, university administrators and others should believe that if adequate resources are brought together in one place, student learning and development will occur. The resource theory in its part of resource availability informs this study and help to frame the role students' experience may play in exposing their viewpoints about student financial aid and its role in stimulating enrollment in Tanzania; on the believe that the discussion makes clear to government, university administrators, policymakers and private sectors on the important of providing fiscal resources to the students who wish to join the postsecondary education.

\section{Literature Review}

\subsection{The Role of financial aid in stimulating students' enrollment}

Research on students' enrollment in higher education yielded findings on how important it is for higher education institutions to develop a complete enrollment system and how this system should be linked to other functional areas such as financial aid, student orientation, housing, counseling, career planning and placement in order to ensure positive enrollment and retention of students (Rentz \& Saddlemire, 1988). Numerous studies have noted the benefit of connecting the enrollment system and financial aid to assist student affairs practitioners within the university to answer important questions like; what kind of financial aid policy to adopt that would aim to attract students who rely on financial aid? (Hossler, 1984).

Prior research has suggested that higher education institutions and other stakeholders in this sector should conduct a marketing research so as to have the type of information desired by most students and parents such as the level of tuition fee and financial aid packages. This plays an important role in determining whether a student will apply to a given institution or not. Thus, the financial aid office at any university plays a vital role in ensuring that the students who rely on financial aid meet the university's requirements (Jackson, 1982; St. John, 1989).

Financial aid in higher education aims to make tuition fees and other academic cost affordable. Financial aid has three main objectives: to increase students' enrollment and persistence, to increase affordability (make higher education cheaper for students and their families) and to promote equality of opportunity (make sure disadvantaged students can go to university) (Gillen, 2010). Research shows that the majority of financial aid in many universities around the world usually falls within three major categories of grants namely, loans, scholarships, and jobs, derived from a variety of sources such as government institutions, private organizations, religious institutions, private companies and other individuals (Coonrod, 2008).

Although a large body of research highlights the importance of financial aid in stimulating enrollment in higher education institutions, other research argue that the current financial aid programs are ineffective in that they often indirectly lead to higher costs per student, with higher tuitions which reduce access and affordability for students from low-income families; because much of the financial aid is structured in such a way that higher education institutions can obtain additional resources (Gillen, 2010; Long, 2008; Ronstadt, 2009).

\subsection{Students' Enrolment and Financial Aid in Tanzanian Higher Education}

From the year 2015, the number of students who finished senior secondary education and qualified to apply for university education has been increasing every year in Tanzania; the rise in enrollment and students' attendance in secondary schools is considered to be one of the factors of this situation. The reason behind this situation is that, in 2015 the Tanzanian government issued Circular 5 on education and training policy 2014, which prescribed the abolition of school fees at the secondary level, including the removal of all forms of fees and contributions (MoVT, 2018). According to NECTA (2019) report, in 2019, a total number of 90,001 students sat for advance secondary school final examination, among whom 88,069 students, representing $98.32 \%$ from different socio-economic backgrounds passed and qualified to apply for higher education (TCU, 2019). Despite this high level of success and qualification for higher education, many of these students did not make it to the university due to several factors such as the inability to meet academic costs, which is a hindrance to the equality of opportunities in accessing higher education, particularly for students from disadvantaged backgrounds (TCU, 2019).

Numerous studies have suggested that students' financial aid should be derived from multiple sources so as to ensure diversity of support to the students. Yet, in Tanzania there is limited information on the involvement of other stakeholders such as private companies, organizations and private individuals in education institutions within the country to provide financial assistance to needy students who qualify for higher education but cannot afford 
the cost. However, in 2004, the Tanzanian government established the Higher Education Students' Loans Board (HESLB); The board is mandated to administer loans to eligible and needy Tanzanian students seeking admission into public and private universities, and to collect repayments for all loans issued to beneficiaries so as to ensure the sustainability of the scheme (HESLB, 2019).

Several researches in Tanzania show that the Tanzanian government, through HESLB, has remained the main source of financial aid for students through its loans scheme. In fiscal year 2017/2018, the education sector in Tanzania was allocated 4.71 trillion Tanzanian shillings, representing 15 per cent of the total budget. HESLB, which is the largest single development project, consumed 47 per cent of the education development budget (UNICEF, 2018). Subject to availability of funds, HESLB may provide loans to cover all or either of the following items: Meals and accommodation (at the rate of Tzs10, 000 per day), tuition fee (Means Testing (MT) is used to determine applicants' neediness for financial assistance and percentage of school fee to be covered), books and stationery, special faculty requirements, research, and field practical training.

In academic year 2018/2019 the government allocated 427.5 billion Tanzanian Shillings, to provide loan to all students eligible to the loan scheme and who wish to apply. 66,000 students applied for the loan while the government's capacity to finance students through disbursement of loan could only cover 33,244 students. This situation led to half of students who applied for the loan scheme to lack financial assistance to cover their academic costs (HESLB, 2018).

The above information shows that many students planning to join higher education in Tanzania rely on financial aid, but due to the inadequacy of government's budget for providing loans to all students applying for financial aid, many lack the opportunity to be enrolled in universities due to high academic costs (i.e., The tuition fee for public and private universities in Tanzania range between TZS 1500,000 (US\$ 691 to TZS 5,000,000 (US\$ 2,160) (TCU, 2019). Anyhow, this situation hindered university access to students who could not afford tuition costs and who could not secure the financial aid either, while other stakeholders such as private sectors, organizations, and even other educational institutions, who ultimately benefit from these higher education products upon graduation, still have little involvement in the provision of students' financial assistance (Memba \& Feng, 2016; Mgaiwa, 2018).

\section{Methods}

A Case study design using qualitative approach was employed in this study given that it was an empirical research designed to reveal students' perspectives on the role of financial aid in equalizing opportunity for higher education beyond those that might be already predicted. To achieve the research aim, in-depth focus-group interviews were employed as a relevant approach in collecting different categories of information, such as, thoughts and understandings of participants (Coles \& Swami, 2012).

\subsection{Case Study}

Case study design was an effective approach in identifying and explaining various layers of settings, thus revealing a multifaceted picture of financial aid and its role in university students' enrollment (Yin, 2018). I deliberately selected two universities as institutional sites that had different enrollment rates in order to obtain diverse experiences from the students, enrollment management and financial aid staff members.

Regarding high enrollment rate among Tanzanian universities, university of Dar-es-salaam (UDSM) stands out as a rich case. UDSM is a well-established, oldest and biggest public university in Tanzania, the university has two constituent colleges, six campus colleges, five schools, five Institutes and eight centers. In academic year 2018-2019, the institution had a total enrollment of 17,098 undergraduate students from different academic levels (UDSM, 2019). The second institutional site is Mzumbe University. Mzumbe University is a public higher education institution, officially recognized by the Tanzania commission for universities (TCU). In academic year 2018-2019, Mzumbe university enrollment ranged between 4,000-4,999 students from different courses and programs. (Basic Statistic Portal, 2019).

\subsection{Sample}

This study was comprised of data from 55 students aged between 20 and 24 years old (30 from UDSM and 25 from Mzumbe). In order to ensure the data collected attain the research aim, ethical issues were highly considered from the first stage of inviting participants to the end of data collection. Voluntariness was significant and all participants were willing to share their experiences about financial aid and enrollment. For student participants, consent letter was provided at the beginning of each focus-group interview with enough time to read and understand the study protocol before the focus-group discussion. To obtain a wide range of viewpoints about financial aid and its role in stimulating enrollment within Tanzanian university, the enrollment management and financial aid staff members were invited in this study to share they are experiences ( 2 from UDSM and 2 from Mzumbe university) to participate in the study through oral consent. All participants involved in this study were allowed to withdraw at any time without any penalty and there was no payment for participation in this study. 


\subsection{Data Collection}

To explore students' experience, the focus-group interviews were prepared with students in both universities by involving students who were under various financial support schemes, either from the government, private sector or dependent on family support to ensure similar grounds of the study. Focus group method helps to influence interaction within the group, makes the students to speak up, gives them the courage to share their experience and provides the opportunity for them to contribute and connect on each other's answers to produce better information for research (Fontana \& Frey, 1994). Guided by purposeful sampling (Patton, 2002), I sought freshmen and sophomore students, as these students, compared to other junior or senior students, still had fresh memories of their experiences when applying for financial aid.

Data collection at each focus group lasted approximately 60 minutes and was conducted in a silent area. During focus group, students were asked open-ended questions, which prompted them to answer by providing a deeper insight on the role of financial aid in stimulating their enrollment and obstacles or challenges that students encounter in the financial aid process. Sample open-ended questions included, "In your own words, describe the role of financial aid on the ability to enroll in university?," "Describe the obstacles you encountered in the current financial aid program?," "Indicate the reasons you choose to apply for financial aid," "Describe how you went about collecting information about financial aid?," "Describe how university pay a role in providing financial assistance to students?," and "Describe how you narrowed down your choices and selected to apply to the current financial aid?"

Semi structured interviews were conducted with four administration officers from admission and financial office ( 2 from UDSM and 2 from Mzumbe university). The interview questions were about how the enrollment rate in their universities were affected by the lack of financial aid for students, whether the universities reached their expectations in terms of recruiting new students each year and how the universities played a role in supporting students financially.

\subsection{Data Analysis and Trustworthiness}

In analyzing focus group data, each student was treated as a separate case. Then, cases were analyzed comparatively. The constant comparative approach (Charmaz, 2005) was also used to compare cases in the study. This approach helped to categorize and compare data from students and staff members with the existing literature and theory. After focus group and semi structured interviews with students and staff members respectively, data were analyzed using a priori codes based on the research questions, and a review of the literature. I gathered a listing of the role of financial aid in stimulating enrollment in university and obstacles that students encounter in the financial aid process reported in the literature. Extra codes were added when the respondents frequently revealed a common theme during focus group and semi structured interviews. As more cases confirmed similar issues, I started to make little generalizations about the cases in the study and later categorized into themes. To ensure the trustworthiness of our data, I confirmed the transcriptions by listening and reading concurrently. I also involved the respondents in member checking to verify the transcripts, if the respondents' experiences were represented as intended.

\section{Findings}

Findings of the study indicated that no participant was receiving full financial aid to cover the education cost. A majority (46) of participants was solely dependent on the financial aid they were receiving, with tiny support from families, because of the low economic condition of the families. This majority was followed by 9 participants who received financial aid from different sources, with support from their families to cover other expenses.

Participants were asked to describe any and all of the role of financial aid in stimulating enrollment in university and obstacles encountered in the current financial aid program. Participants' responses centered around five general themes: low economic condition and higher university cost was the factor most frequently mentioned by many participants, as response to the role of financial aid to stimulate enrollment in their current universities, followed by obstacles they encountered, which included: financial aid program leaving them with unmet needs, low contribution of universities in providing the financial assistance, and inadequacy of private financial aid provision.

\subsection{Low Economic Condition and Higher Cost}

An initial participants' experience about how the financial aid program is worthwhile for students' enrollment, the majority of participants reported the great influence of financial aid programs on their enrollment, especially those who were coming from low-income families. The financial aid helps to reduce burden on the families by enabling them to pay for tuition fees and some other expenses. The following comment illustrates how financial aid plays an important role for students from low economic background:

I receive loan from the government which pays $80 \%$ of annual university fees and money for living allowance in every semester, then I use the money for living allowance to pay remaining $20 \%$ of university fee ... 
sometimes it became very difficult for me because the money is not enough, but I have no option because I totally depend on the loan I get from the government... So financial aid plays a great role in my university enrollment.

Another participant reported that, due to the delay in obtaining financial aid to cover his academic costs, he could not bear it anymore and wanted to quit studies because his family was not in the position to pay for his academic expenses. Later, he got the financial aid and this helped him to enroll in his current university.

I solely depend on the loan from the government, because of the low economic condition of my family, in my first year I wanted to give up joining the university, because my loan was late, it was the only source of money I was waiting to be able to do my registration... finally, the Higher Education Loans Board (HESLB) deposit the money which helped me to be enrolled in this university. If it had delayed for another two weeks, I would have found some other thing to do and quit studies.

Commenting on their experiences in the role of financial aid in stimulating enrollment in higher education, similar result of low economic condition was explained by admission officers in both universities when interviewed:

I agree that the student financial aid became an important factor for students to join the universities. The students always did their university registration very late and when you asked them why? they said they had no money to do registration because apart from tuition fee, there are other costs associated with registration that a student must pay even before he/she receive financial aid such as housing, health care, students and organization. Therefore, students from low-income families always find it difficult to gather this amount of money.

For those students who are receiving financial aid in our university, $90 \%$ of them are getting loan from the government through HESLB. Due to insufficient budget of the government, financial support is not for every student who applies for it. I admit that sometimes, it affects enrollment rate in our university... So, it is true that financial aid plays an important role for students' enrollment, especially those who are coming from low economic backgrounds and who represent the majority.

The above experiences as demonstrated by admission officers have also provided further evidence of the positive role of financial aid in accessing university education. Summarizing all the findings relating to obstacles encountered by students in the financial aid process (Research Question 2), it is clear that students encounter several obstacles in the current financial aid program. The following themes were revealed:

\subsection{Financing Aid Program Left Students with Unmet Needs}

In spite of the financial support from the government through disbursement of loans, many participants revealed that they were still left with unmet needs that became a burden for them and their families. The insufficient financial aid package students received to cover their whole tuition fee and living expenses were the main reasons for the students' many unmet needs. One participant, who was receiving loan from the government, testified to the insufficiency of the financial aid package as follows:

I'm receiving loan from the government to cover small part of my university fee (only $20 \%$ ), the remaining part is covered by my family, although the burden is still very high to my family...At the time I joined university I was required to pay the remaining part of the school fee and other costs associated with registration. It was a lot of money to my family...My father decided to sell one of his farms in the village to pay for my education cost and to make some savings for coming semesters. I'm very worried about continuing to study if my family is not able to pay for education cost in the future.

\subsection{Limited Contribution from Universities}

Another key theme that emerged from the data was low contribution of universities in providing financial assistance to the admitted students and those who wish to join university. Despite government support to subsidize higher education tuition fees through students' loan, paid straight to the universities, Tanzanian universities still have limited financial assistance programs for students. Many participants responded on the limited opportunities of financial aid from their universities. The following comment illustrates how students realized the limited contribution of universities in providing financial aid to needy students:

In my first semester of second year, I heard that there was financial aid opportunity in our university. But there were only 10 chances available...I decided to apply, the competition was very high because more than 100 students applied. Unfortunately, I did not get it.

In answering the question: describe the role of university student financial services in supporting needy students? the financial officers of both universities admitted that universities have few financial aid programs to support students and this is due to lack of enough funds to support many students. As one financial officer explained:

In our university we have a student financial service for undergraduate students. It is called the merit scholarship. This program is only for Tanzanian students admitted in our university. But, due to inadequate 
funds the program could not support many students, for example, in the 2019/2020 academic year, only 52 chances were available for undergraduate and graduate students.

\subsection{Lack of Information about Financial Aid Opportunities}

Echoing the findings of Kane and Avery (2004) asserted that most often, the low-income families (especially in rural areas) had the least amount of information about university costs and financial aid available. This trend was reflected by some participants who lacked formal information channel about financial aid available.

Before I join the university, I was intimidated by news stories about financial aid opportunities, with the impressions that financial aid is only for intelligent students, who had high grades in their final high school examination. This belief was depressing me because I come from poor family.

Though this theme is confirmed through one quote, many respondents commented about the lack or have little accurate information of financial aid opportunities. This finding has negative impact on university access, because lack of accurate information influenced parents not to bother preparing their children for university studies because they believed that they could not afford to pay for the university costs.

\subsection{Inadequate of Private Financial Aid}

Private financial aid is grant monies awarded to students from private sources (e.g., companies, community foundations, independent foundations, educational trusts, or individual donors) (McSwain et al., 2005). Inadequacy of private financial aid provision was another theme that emerged. The majority of participants did not identify any source of financial aid from private providers, a part of financial aid they received from the government through loan. Responding to focus group questions regarding the availability of various private financial aids, the majority of participants (49) reported that they did know any kind of private financial aid provided in Tanzania. As one participant stated:

I don't know any source of private financial aid. After completion of my high school, I tried to search on the internet other sources of financial aid apart from government loans, but I didn't find any information about private financial aid in Tanzania. Instead I found several consultancy agents specialized in finding scholarship for students, particularly in countries abroad like China, Hungary, and Canada, but most of the agents had high service charges which my parents could not afford. Now I'm receiving loan from the government to cover $45 \%$ of my tuition fees.

Other 6 participants, found information on few private financial aid providers but it was difficult for them to get financial assistance from them due to limited chances available and the high academic performance required from applicants. As one participant explained:

I found few private financial aid providers, with very high eligibility requirements, very limited number of students needed and a merit-based system of scholarship grants.

Commenting on the issue of private financial aid, the financial officer admitted that in Tanzania, government shouldered the burden of financing undergraduate students for more than $90 \%$ through disbursement of loans. However, other stakeholders such as private sectors, organizations, and even other educational institutions, who ultimately benefit from these higher education products upon graduation, still have little contribution in the provision of students' financial assistance and this causes the whole students financial aid system to became lopsided. As one financial officer stated:

Is true that many students don't know the existence of private financial aid providers and how they operated in the country. There is no clear data which show the annual amount spent by private financial aid providers to sponsor students. When it happens that they sponsor a student, sometimes they don't pass through the university's financial offices, especially those scholarships awarded directly to students. As a result, there is difficulty collecting data on private financial aid providers available in the country.

\section{Discussion}

This study's findings encourage higher education administrators, policymakers, private sectors, and the government to reconsider financial aid programs and their role in promoting students' enrollment at university level. Previous research indicates that the number of student enrollment in universities is related to their family income, such that as the cost of university education decreases, more families are able to afford to send their children to university (Gillen, 2010; Jackson, 1982; St. John, 1989). This study found that higher cost of university education made underprivileged students to be unable to pay for university fees and always affected their enrollment in these universities if they could not secure any financial support on time or at all. The data also indicated that 46 participants were highly dependent on financial assistance to be enrolled in their current universities because of low economic conditions.

Gillen (2010) posited that once financial aid is considered, the remaining costs to be paid by students become less. The findings in this study indicated that the majority of participants, after accessing the financial aid (majority received loan from the government), faced additional costs that were beyond their income. The situation caused 
many students from low-income backgrounds to be left with unmet needs. The findings from this study add to our understanding that effective financial aid programs which do not leave students with unmet need, will help to create positive impact on students' enrollment and increase their chances of staying in the university till graduation.

McSwain et al (2005) asserted that, "The private financial aid is simply aiming to enhance choices and backing the government in financing needy students hoping to go to universities. It is an important aspect of any nation's system to enhance access to higher education" (p.149). This study, however, found ample evidence of the inadequacy of private financial aid provision in Tanzania and it effect on the enrollment of students who were solely dependent on financial aid. The findings also indicated that administrators in higher education lack accurate information about the availability of private financial aid, which still remains as the least understood source of student financial assistance.

This study's findings suggest that formal channels through which students get accurate information about available financial aid may play a role in fostering university access to students from low economic background, the role of university administrators should be examined in creating awareness and providing information to students on available financial aid from different sources when they are recruiting new students (e.g., student affairs professionals can assist with gathering of information about available financial aid providers and sharing this information to the prospective students seeking university enrollment through admission platforms).

This study suggests a potential implication for higher education and student affairs practitioners interested in providing financial aid to stimulate students' enrollment that, need-based aid is more effective in increasing access for low-income students than other forms of aid. This enabled the enrollment of students who would not otherwise be able to afford university education; moreover, it is equalizing opportunity for higher education.

Additionally, the findings from this study suggest that universities should intensify their efforts in supporting students by exploring specific ways of working together with private financial aid providers to ensure effectiveness in the financial aid provision. I suggest that higher education should search a complete list of multiple private financial aid providers and maintain it to avoid the difficulty in accessing the information, a detailed list which could be shared in the university website will improve the quality and accuracy of the data needed by prospective students.

Within the constraints of research, I practically recruited few students from only two universities. It is therefore suggested that future research could develop further study to investigate the perceptions of students, administrators and financial aid providers across various institutions. Future quantitative or mixed-methods research could provide a better understanding and richer data on why the current financial aid program is ineffective. Moreover, I call upon student affairs administration, including its associations (e.g., admission department) to move beyond student financial aid, with more research, specifically to provide a better understanding of how other factors can influence students' enrollment in higher education institutions.

\section{Conclusion}

This study offers empirical evidence of financial aid and its role in stimulating enrollment in higher education institutions. In providing an analysis of students' experiences and opinions of administrators in higher education, this study provides significant implications for the field of higher education, regarding financial aid as a crucial component of improving access to higher education for the students from different economic backgrounds. I advocate for multiple sources of financial aid to enhance choices and backing the government in financing needy students.

\section{References}

Basic Statistic Portal. (2019). Enrollment degree and non-degree in Tanzania universities. Retrieved from http://statistics.go.tz/dataset/a8c972f1-f78b-497b-

Cabrera, A., Nora, A., \& Castaneda, M. (1993). College persistence: Structural equations modeling test of an integrated model of student retention. Journal of Higher Education, 64(2), 143-64. doi: 10.2307/2960026

Charmaz, K. (2005). Grounded theory in the 21st century: A qualitative method for advancing social justice research. In N. K. Denzin \& Y. S. Lincoln (Eds.), Handbook of qualitative research (3rd ed., pp. 507- 535). Thousand Oaks, CA: SAGE.

Coles, R., \& Swami, V. (2012). The sociocultural adjustment trajectory of international university students and the role of university structures: A qualitative investigation. Journal of Research in International Education, 11(1): 87-100. doi: https://doi.org/10.1177/1475240911435867

Coonrod, L. (2008). The effects of financial aid amounts on academic performance. The Park Place- economist. Retrieved from http://digitalcommons.iwu.edu/parkplace/vol16/iss110

Dorsch, M., Törnblom, K., \& Kazemi, A. (2016). A review of resource theories and their implications for understanding consumer behavior. The Association for Consumer Research. Retrieved from http://dx.doi.org/10.1086/688860

Fontana, A., \& Frey, J. (1994). Interviewing: The art of science. In N. K. Denzin (Ed.), The handbook of qualitative 
research (Pp. 361-76). Thousand Oaks, CA

Gandhi, D. (2018). Higher education enrollment grows in sub-Saharan Africa along with disparities in enrollment by income. Africa in Focus. Retrieved from: https://www.brookings.edu/blog/africa- infocus/2018/01/10 /

Gillen, A. (2010). Financial aid in theory and practice. Why it is ineffective and what can be done about it. In J. c. Hall (Ed), Doing more with less: making colleges work better (pp. 15 -51). Washington, DC

Higher Education Students Loans Board (HESLB). (2019). Guidelines and criteria for Issuance of Students' loans in Tanzania. Retrieved from https://www.heslb.go.tz/docs/guideline/guidelines_2019_16.pdf

Higher Education Students Loans Board (HESLB). (2018). Report of Tanzanian student loan distribution in academic year 2018/2019. Retrieved from https://nukta.co.tz/read/heslb

Hobfoll, E. (1989). Conservation of resources. American psychologist, 44(3), 512-24.

Hobfoll, E. (2002). Social and psychological resources and adaptation. A review of general psychology. American psychologist, 6(12), 307-24.

Hossler, D. (1986). Enrollment Management: An Integrated Approach. San Francisco, CA: Jossey-Bass.

Ishengoma, J.M. (2011). The socio-economic background of students enrolled in private higher education institutions in Tanzania: implications for equity. Journal of Education and Development. Retrieved from https://www.semanticscholar.org/paper/ThesocioeconomicbackgroundofstudentenrolledIshengoma/

Jackson, G. (1982). Public Efficiency and Private Choice in Higher Education. Journal of Education Evaluation and Policy Analysis, 4(2), 237-247. doi: 10.2307/1164016

Kane, J., \& Avery, C. (2004). Student perceptions of college opportunities: The Boston coach program. In C.M. Hoxby (ed), The economics of where to go, when to go, and how to pay for It (pp. 355 - 394). University of Chicago Press

Long, B.T. (2008). What Is Known About the Impact of Financial Aid? Implications for Policy. The National Center for Postsecondary Education. Columbia University. Retrieved from https://ccrc.tc.columbia.edu/media/k2/attachments/impactfinancial-aid-ncpr.pdf

McSwain, C., Cunningham, A., Keselman, Y., Merisotis, J., Hardge, L., \& Krichels, S. (2005). Private Scholarships Count Access to Higher Education and the Critical role of the Private Sector. A report by institute for higher education policy. www.scholarshipamerica.org

MoVT. (2018). Report on removal of fee for public secondary school in Tanzania. Retrieved from http://www.moe.go.tz/en/about-us/background.html

Mgaiwa, J. (2018). The Paradox of Financing Public Higher Education in Tanzania and the Fate of Quality Education: The Experience of Selected Universities. Sage Open, 1-16, doi: 10.1177/2158244018771729

Memba, Z., \& Feng, J. (2016). Significance of Trends on Enrolment, Budget and Actual Expenditure in the Examination of Higher Education Financing in Tanzania. Journal of Education and Practice. Retrieved from www.iiste.org

NECTA, (2019). Advanced certificate of Secondary School Education Examination (ACSEE). Retrieved from https://www.necta.go.tz/acsee

Patton, M. Q. (2002). Qualitative research and evaluation methods (3rd ed.). Thousand Oaks, CA: SAGE

Rentz, L., \& Saddlemire, L. (1988). Student Affairs Functions in Higher Education. Springfield. Charles C. Thomas.

Ronstadt, R. (2009). Don't fix the student aid system-kill it. Chronicle of Higher. Retrieved from https://eric.ed.gov/?id=EJ832546

St. John, P. (1989). The Influence of Student Aid on Persistence. Journal of Student Financial Aid. Retrieved from https://ir.library.louisville.edu/jsfa/vol19/iss3/5

TCU, (2019). Undergraduate Admission Guidebook for 2019/2020 Academic Year. Retrieved from https://www.tcu.go.tz/?q=content/undergraduate-admission

UNESCO. (2009). World Conference on Higher Education: The New Dynamics of Higher Education and Research for Societal Change and Development. Paris, UNESCO. Retrieved from https://unesdoc.unesco.org/ark:/48223/pf0000189242

UNICEF. (2018). Education Budget Brief 2018 in Tanzania: Key Messages and Recommendations. Retrieved from https://www.unicef.org/tanzania/media/1236/file/UNICEF-Tanzania

UDSM. (2019). Facts and Figures 2011/12 - 2018/19: Directorate of Planning and Development. University of Dar-es-Salaam. Retrieved from https://www.udsm.ac.tz/web/index.php/facts-and- figures

World Bank. (2017). School enrollment, tertiary (\% gross) - Sub-Saharan Africa. Retrieved from https://data.worldbank.org/indicator/SE.TER.ENRR?locations $=$ ZG

Yin, R. K. (2018). Case study research and application: Design and Method. Thousand Oaks, California: SAGE Publication Inc. 